\section{УПРАВЛІНСЬКИЙ АНАЛІЗ: СУТНІСТЬ ТА \\ ЗНАЧЕННЯ У ПРИЙНЯТТІ РІШЕНЬ ${ }^{\odot}$}

О.Ф. ТОМЧУК,

кандидат економічних наук, доцент, доцент кафедри аналізу та статистики

Т.О. МУЛИК, кандидат економічних наук, доцент, доцент кафедри аналізу та статистики

Л.I. ФЕДОРИШИНА, кандидат історичних наук, доцент, доцент кафедри аналізу та статистики Вінницький національний аграрний університет (м. Вінниця)

У статті визначено місие управлінського аналізу в системі управління підприємством. Розглядається його вплив на ефективність підготовки $i$ прийняття управлінських рішень. Встановлено, що внутрішній управлінський аналіз покликаний для обгрунтування управлінських рішень, прийнятих керівництвом підприсмства та для підвищення їх ефективності. Зовнішній аналіз потрібний зовнішнім користувачам для самостійного ознайомлення 3 діяльністю підприємства, щчо їх иікавить за даними фінансової звітності.

Виділено особливості управлінського аналізу, його місие в системі управлінського обліку $i$ економічного аналізу, етапи прийняття i реалізації управлінських рішень. Визначено роль інформачії в системі прийняття управлінських рішень, щзо дозволяє мати певну уяву про наявність або про відсутність відхилень від заданих значень досліджуваного процесу, а також виявити ту або іншу назріваючу проблему.

Наведено послідовність етапів управлінського аналізу, які завершуються комплексною оцінкою ефективності прийнятих рішень.

Удосконалено поняття «управлінський аналіз», який покликаний обгрунтовувати управлінські рішення, щзо приймаються на підприємстві, яке функиіонує в умовах глобалізаиії ринкових прочесів та запропоновано відповідне його визначення.

Ключові слова: управлінський аналіз, управлінський облік, економічний аналіз, менеджмент, прийняття рішень, особливості аналізу.

Рис.: 3. Літ.: 12.

\title{
MANAGEMENT ANALYSIS: THE ESSENCE AND SIGNIFICANCE IN DECISION-MAKING
}

TOMCHUK Olena

Candidate of Economic Sciences, Associate Professor, Associate Professor of analysis and statistics Department Vinnitsia National Agrarian University

MULYK Tetiana, Candidate of Economic Sciences, Associate Professor, Head of the Analysis and Statistics Department, Vinnytsia National Agrarian University

FEDORYSHYNA Lydia

Candidate of History Sciences, Associate Professor, Associate Professor of analysis and statistics Department

Vinnitsia National Agrarian University

(Vinnytsia) 
http://efm.vsau.org/

The article defines the place of management analysis in the system of enterprise management. Its influence on the effectiveness of preparation and making of managerial decisions is considered. It is investigated that internal management analysis is intended to substantiate the managerial decisions taken by the management of the enterprise and to increase their efficiency. An external analysis is required by external users for independent familiarization with the activities of the enterprise that they are interested in according to financial reporting.

The features of management analysis, its place in the system of management accounting and economic analysis, stages of making and implementing managerial decisions are highlighted. The role of information in the system of management analysis is determined.

The expediency of introducing the concept of "integrated management analysis", which is intended to justify managerial decisions that are made at the enterprise, which functions under conditions of globalization of market processes.

It is proposed to provide full and most accurate definition of management analysis taking into account its features.

Key words: management analysis, management accounting, economic analysis, management, decision making, features of analysis.

Fig.: 3. Ref.: 12 .

\section{УПРАВЛЕНЧЕСКИЙ АНАЛИЗ: СУЩНОСТЬ И ЗНАЧЕНИЕ В ПРИНЯТИИ РЕШЕНИЙ}

ТОМЧУК Елена Феликсовна кандидат экономических наук, доцент, доцент кафедры анализа и статистики Винницкий национальный аграрный университет

МУЛЫК Татьяна Алексеевна, кандидат экономических наук, доцент, заведующая кафедрой анализа и статистики, Винницкий национальный аграрный университет

\section{ФЕДОРИШИНА Лидия Ивановна кандидат исторических наук, доцент, доцент кафедры анализа и статистики Винницкий национальный аграрный университет} (2. Винница)

В статье определено место управленческого анализа в системе управления предприятием. Рассматривается его влияние на эффективность подготовки и принятия управленческих решений. Исследовано, что внутренний управленческий анализ предназначен для обоснования управленческих решений, принятых руководством предприятия и для повышения их эффективности. Внешний анализ нужен внешним пользователям для самостоятельного ознакомления с деятельностью предприятия, что их интересует по данным финансовой отчетности.

Выделены особенности управленческого анализа, его место в системе управленческого учета и экономического анализа, этапы принятия и реализации управленческих решений. Определена роль информации в системе принятия управленческих решений.

Доказана челесообразность введения понятия “комплексный управленческий анализ”, который призван обосновать принимаемые управленческие решения на предприятии, функционирующем в условиях глобализации рыночных процессов.

Предложено дать полное и наиболее точное определение управленческому анализу, учитывая его особенности.

Ключевые слова: управленческий анализ, управленческий учет, экономический анализ, менеджмент, принятие решений, особенности анализа.

Рис.: 3. Лит.: 12.

Постановка проблеми. Фінансова криза, яка охопила економіку України сьогодні, негативно впливає на фінансово-господарську діяльність підприємств, результати якої цікавлять як зовнішніх так і внутрішніх користувачів. За цих умов зростає роль управлінського аналізу, який покликаний перетворити економічну і неекономічну інформацію в придатну для прийняття рішення. Він дозволяє знизити невизначеність при прийнятті управлінського рішення та створює 


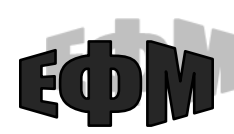

http://efm.vsau.org/

стійку і системну основу для його раціонального застосування. Управлінський аналіз в процесі управління виступає як елемент зворотного зв'язку між системою, що управляє і керованою. Ці системи взаємопов'язані іє замкнутим контуром управління.

Особливе значення управлінський аналіз набуває в сільському господарстві, специфіка якого знаходиться в прямій залежності від природно-кліматичних умов. Сільськогосподарське виробництво пов'язане з управлінням складної агроекосистеми, що обумовлює сезонність сільського господарства і пов'язаних з ним технологічно сфер переробки, зберігання, ресурсного і інфраструктурного забезпечення. Досягти конкурентоспроможності і економічного зростання в умовах нестабільної економіки можливо за умови вивіреної стратегії і тактики, своєчасного ухвалення обгрунтованих управлінських рішень 3 урахуванням висновків i результатів управлінського аналізу. Без уміння науково обгрунтовувати та правильно оцінювати ефективність рішень, що приймаються на основі даних аналізу, управління підприємством не може бути ефективним, зменшується його роль як двигуна, прискорювача економічного розвитку [1, с. 10]. Невирішеною частиною проблеми залишається контекст урахування галузевої специфікації управлінського аналізу.

Аналіз останніх досліджень і публікацій. Протягом декількох століть вчені приділяли значну увагу впливу аналізу на тенденції розвитку економічних процесів, можливих резервів підвищення ефективності виробництва підприємства, особливо за сучасних умов господарювання. Дослідження ролі аналізу при прийнятті управлінських рішень викладено в працях вітчизняних науковців, таких як І.В. Гончарук [12], О.М. Гайдаєнко [10], Г.М. Калетнік [5], Т.М. Ковальчук, Т.О. Мулик [9], С.В. Мних [6] й інших.

У зарубіжній літературі питання практичного втілення результатів управлінського аналізу в діяльність підприємств розглядали М.А. Вахрушина [8], О.Т. Зирянова, Н.А.Нікіфорова [7], Г.В.Савицька тощо. Незважаючи на всю широту вивчення фінансового аналізу, як одного із видів економічного аналізу, питання, які стосуються вивчення змісту і сутності управлінського аналізу, до цих пір залишаються мало висвітленими і неоднозначними через різні трактування вчених, тому потреба подальшого проведення наукових досліджень в цій сфері є актуальною для забезпечення об'єктивності та достовірності результатів аналізу, прийняття обгрунтованих управлінських рішень.

Мета статті. Метою статті є висвітлення суті та значення управлінського аналізу у прийнятті рішень.

Виклад основного матеріалу. Аналіз тісно пов'язаний зі всіма функціями управління $\mathrm{i}$ забезпечує їх виконання, а тому $\epsilon$ всезагальною функцією управління. Прийняття оптимальних управлінських рішень перетворилося зараз у дуже важливу проблему. Аналіз бере участь у всіх етапах процесу прийняття управлінського рішення і сприяє покращенню управлінської діяльності [2, с. 11, 12]. Як відомо, під управлінням розуміється систематична, свідома дія на процес громадської праці або іншої діяльності, спрямоване на досягнення поставленої мети шляхом найбільш ефективного використання фінансових, матеріальних, трудових і інших ресурсів. Система управління впливає на об'єкт за допомогою загальних функцій, взаємозв'язок і взаємодія яких утворюють замкнутий цикл управління.

Термін “аналіз" означає розділення на складові частини. 3 самого визначення витікає і його суть: розділення проблеми на складові частини, доступніші для подальшого поглибленого вивчення. Далі за допомогою спеціальних методів, прийомів, способів вирішуються проблеми, які виникли і поставлені завдання. Така діалектика пізнання базується на єдності аналізу і синтезу як наукових методів вивчення реальності [3, с. 7].

Поняття “управлінський аналіз” прийшло в Україну з англо-американської школи. Зарубіжні учені трактували управлінський аналіз як аналіз витрат в першу чергу виробничих підприємств, де більше уваги приділяється калькуляції собівартості, методам обліку витрат, виділенні центрів витрат і центрів відповідальності, плануванні витрат і аналізі відхилень від плану (бюджету). Це методи створення інформації, необхідної для управління підприємством. Але однією тільки інформацією про витрати дані, необхідні для прийняття управлінських рішень, далеко не обмежуються.

Успішне управління фінансово-господарською діяльністю підприємства повинно грунтуватися на використанні структурованих та достовірних даних про фінансовий стан підприємства, його зміну та прогнозну динаміку розвитку [4, с. 4]. Відповіді на усі ці питання містять дані як фінансового, так і управлінського аналізу. 
У економічній літературі є присутніми різні трактування визначення “управлінський аналіз" залежно від вибраних за основу ознак. Так, однією з найбільш поширених ознак є управлінський, згідно 3 яким виділяють три складових управлінського аналізу: перспективний (прогнозний) аналіз, оперативний аналіз і поточний (ретроспективний) аналіз, кожному з яких властиве рішення власних завдань [10, с. 4].

У міру розвитку управлінського аналізу в Україні стає актуальним і навіть модним поняття "менеджмент". Цей термін також прийшов до нас із зарубіжної практики. Основоположниками менеджменту як науки про управління являються такі західні учені, як: М.Х. Мескон, И. Ансофф, М. Портер. А. Файоль та інші. Вітчизняні економісти, провівши дослідження в області менеджменту стосовно українських умов функціонування, асоціюють менеджмент з управлінським аналізом. Хоча сам термін “менеджмент" означає спосіб, манеру спілкування з людьми, владу і мистецтво управління, особливого роду уміння і адміністративні навички. На перший погляд, здається, що це визначення досить містке і абстрактне. І це дійсно так. Адже фінансові менеджери вирішують питання, пов'язані із фінансовим аналізом і плануванням, управлінням реальними та фінансовими інвестиціями, управлінням рухом грошових коштів, емісійною, амортизаційною та податковою політикою [5, с. 31]. На нашу думку, що менеджмент $\epsilon$ практичним додатком управлінського аналізу, а управлінський аналіз - фундаментом менеджменту.

Ринкова економіка потребує диференціації аналізу на внутрішній управлінський і зовнішній фінансовий. Так вважає велика кількість вітчизняних учених, і 3 ними важко не погодитися. Причому одними 3 головних відмінних ознак внутрішнього управлінського і зовнішнього фінансового аналізу є суб'єкти аналізу і інформаційна база.

Є.В. Мних зазначав, що споживачами аналітичної інформації управлінського та фінансового аналізу є різні групи користувачів, однак ії зміст може мати лише ті характеристики, які відповідають їхнім інтересам та захищають комерційну таємницю. Суб'єкти внутрішнього управлінського аналізу адміністрація та залучені нею аудитори і консультанти. Вони хоча і не зацікавлені у результатах господарської діяльності, та зобов'язані згідно 3 контрактом захищати інтереси господарського суб'єкта та сприяти зростанню його ділової активності. Інформаційна база внутрішнього управлінського аналізу дуже багата й охоплює потоки нормативної, облікової, планової, звітностатистичної та зовнішньої публічної інформації, а також дані спеціальних обстежень, опитування спеціалістів, преси та інше [6, с. 58, 59]. Слід зазначити, що тільки керівництво підприємства може поглибити аналіз, використовуючи не лише дані звітності, але і дані усієї системи господарського обліку у рамках управлінського аналізу, що проводиться з метою управління.

Суб'єкти фінансового аналізу - адміністрація господарського суб'єкта й зовнішні користувачі. Палітра суб'єктів зовнішнього фінансового аналізу більш різноманітніша. Погоджуючись і далі із твердженнями Є.В. Мниха, зазначимо, що усі ці суб'єкти аналізу можуть використати лише дані публічної фінансової звітності про діяльність підприємства, що не розкривають комерційної таємниці підприємства. Таким чином, внутрішній управлінський аналіз покликаний для обгрунтування управлінських рішень, прийнятих керівництвом підприємства та для підвищення їх ефективності. Зовнішній аналіз потрібний зовнішнім користувачам для самостійного ознайомлення 3 діяльністю підприємства, що їх цікавить за даними фінансової звітності. Крім того, управлінський аналіз включає у свою систему не лише виробничий, але $\mathrm{i}$ фінансовий аналіз, без якого керівництво підприємства не може реалізувати фінансову стратегію підприємства. Вважаємо, що доцільно ввести таке поняття, як комплексний управлінський аналіз. Цей вид управлінського аналізу покликаний обгрунтувати управлінські рішення, що приймаються на підприємстві, яке функціонує в умовах глобалізації ринкових процесів [6, с. 59].

Проаналізувавши різні точки зору відносно суті управлінського аналізу, його визначення, можна зазначити, що у більшості праць визначення управлінського аналізу носить абстрактний характер, тобто, немає точного повного визначення самого поняття, а також його змісту. Але все таки, незважаючи на відмінності в точках зору, вітчизняні науковці сходяться в наступному: управлінський аналіз - це аналіз, призначений для внутрішнього користування, він носить закритий (конфіденційний) характер і призначений для ухвалення оперативних управлінських рішень.

Дослідивши різноманітні підходи до суті управлінського аналізу, можна виділити наступні особливості управлінського аналізу [7, с. 22; 8, с. 29] (рис. 1):

Галузева спрямованість управлінського аналізу полягає в застосуванні спеціальних методик залежно від техніко-економічних особливостей підприємства, на відміну від фінансового аналізу, що проводиться по загальних методиках. 


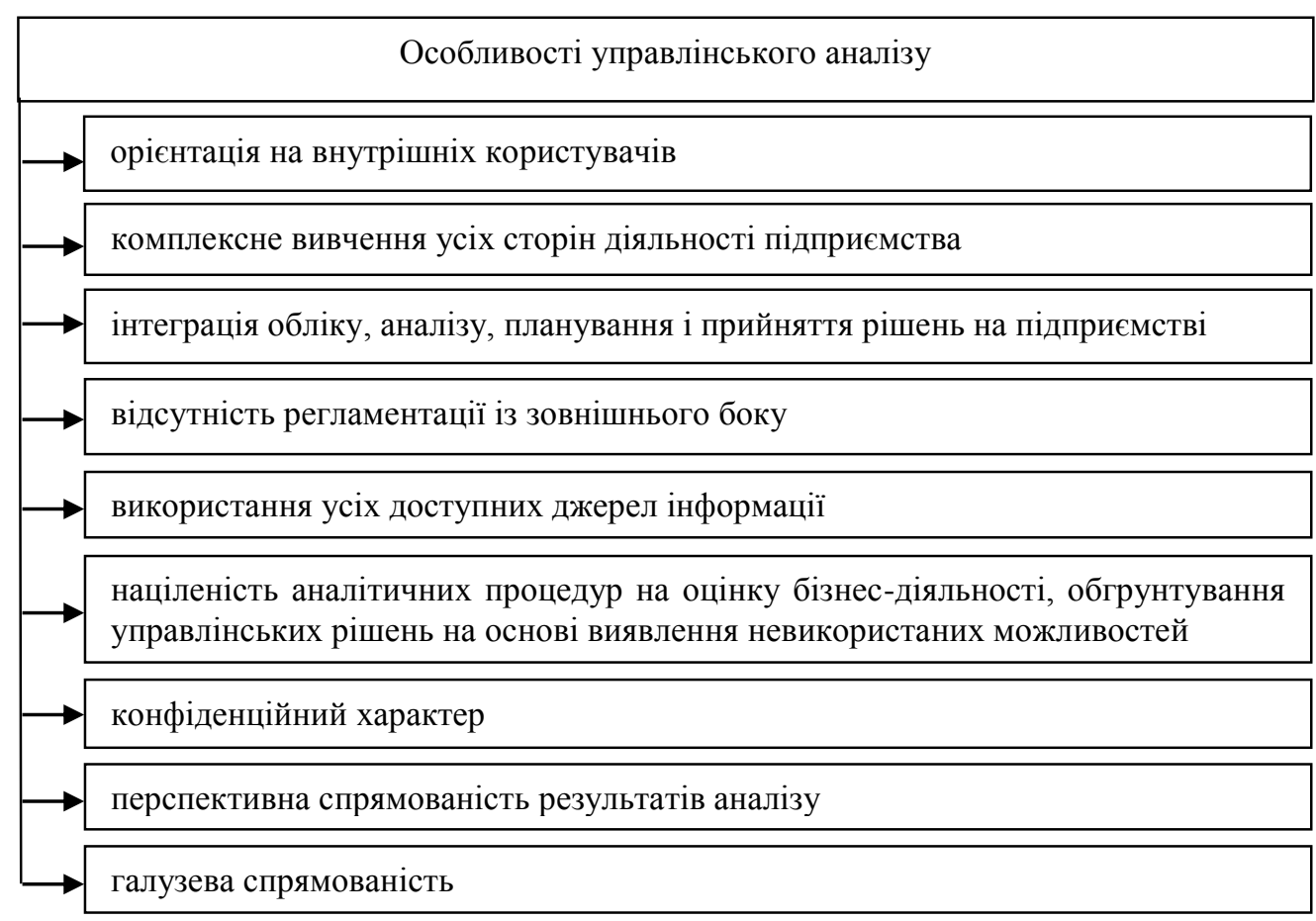

Рис. 1. Особливості управлінського аналізу

Джерело: побудовано авторами на основі [7, с.22; 8, с. 29]

Продовжуючи дослідження, слід зазначити ще дуже важливий аспект. Одним із істотних i дискусійних $є$ питання про місце управлінського аналізу в системі управлінського обліку i економічного аналізу. Т.О. Мулик та M.I. Гордієнко наголошують на тому, що одні учені дотримуються думки про зв'язок управлінського аналізу з управлінським обліком, інші, у свою чергу, визначають управлінський аналіз як складову частину економічного аналізу [9, с. 9-11].

Виокремлення у бухгалтерському обліку фінансового, що сприяє формуванню інформації для зовнішніх користувачів і управлінського, дані якого призначені, головним чином, для менеджерів підприємства, дозволяє використовувати аналогічний підхід i до класифікації економічного аналізу. При цьому Г.М. Калетнік та В.М. Ціхановська звертають свою увагу, що основним завданням фінансового аналізу є процес дослідження фінансового стану і основних результатів фінансової діяльності підприємства 3 метою виявлення резервів підвищення його ринкової вартості і забезпечення ефективного розвитку [5, с. 36]. Але при всій значущості цього виду аналізу основний його недолік полягає у відсутності оперативності, що не дозволяє керівникам швидко оцінити досягнуті результати, розрахувати ефективність діяльності окремих структурних підрозділів, оперативно використовувати отриману інформацію в управлінських цілях. Ці завдання не є прерогативою зовнішнього (фінансового) аналізу; вони вирішуються в процесі проведення внутрішнього (управлінського) аналізу [10, с. 7].

Управлінський аналіз - це аналіз бізнес-діяльності з метою прийняття оптимальних управлінських рішень. Від правильності і результативності управлінського аналізу залежить основний результат прибуток, який згодом стає об'єктом фінансового аналізу, тобто кожен і цих видів аналізу вирішує своє завдання єдиної стратегії аналізу па підприємстві. Щодо управлінського аналізу відносно управлінського обліку, то можна з упевненістю сказати, що там, де підприємством чітко сформульовані потреби в управлінському обліку, стає можливим ефективне застосування управлінського аналізу.

Економічний аналіз займається конкретним пізнанням процесів господарювання, отже, може з'єднати формальну схему теорії прийняття рішень 3 конкретною суттю вирішуваної проблеми. Для прийняття правильного управлінського рішення необхідне його аналітичне обгрунтування [2, c. 12]. Місце аналізу в процесі управління можна характеризувати за допомогою завдань, що стоять перед ним. Виникає необхідність з'єднання кількісного і якісного аналізу управлінських процесів, а також вдосконалення аналітичного забезпечення процесу прийняття рішень.

Розподіл аналізу є дещо умовним, оскільки обидва види аналізу доповнюють один одного інформацією, взаємозв'язані між собою і забезпечують управлінську систему аналітичними даними про діяльність підприємства, про очікувані параметри його розвитку, як на найближчу, так і на 
віддалену перспективу [6, c. 59]. Протиставляти управлінському аналізу слід не взагалі фінансовий аналіз (як аналіз фінансових показників), а зовнішній фінансовий аналіз або фінансовий аналіз для зовнішніх користувачів інформації. У свою чергу, управлінський аналіз поєднує виробничий і фінансовий аналіз, тобто йому за визначенням, як інформаційно-аналітичному забезпеченню рішень, що приймаються на підприємстві, властива комплексність підходу до виробничих і фінансових показників.

У світовій практиці управлінський аналіз традиційно вважається складовою частиною управлінського обліку, яка займається інформаційно-аналітичним забезпеченням керівництва підприємства. Управлінський аналіз покликаний забезпечити управлінський апарат підприємства інформацією, необхідною для управління і контролю за діяльністю підприємства. Велика частина аналітичної інформації, що пов'язана з аналізом ресурсів виробництва, $є$ проміжною інформацією, яка зрештою відбивається в результативних показниках. Таким чином, аналіз у процесі управління виступає як елемент зворотного зв'язку між системами, що управляють i керованою, який $\epsilon$ процесом інформування зацікавлених керівників про відповідність фактичних результатів діяльності очікуваним або бажаним [10, с. 9$]$.

Правильність прийнятих рішень залежить від забезпеченості керівників у повній мірі аналітичними даними, які розкривають стан фінансово-господарської діяльності підприємства i нестача яких негативно впливає на різні рівні управління. Облікова інформація для цілей управління на будь-якому рівні має бути відповідним чином підготовлена і інтерпретована на основі певних методів аналізу.

У західній практиці управління особлива роль відводиться управлінському обліку. Управлінський облік являє собою процес ідентифікації, вимірювання, накопичення, аналізу, підготовки, інтерпретації та надання фінансової інформації, необхідної управлінській ланці підприємства для здійснення планування, оцінювання та контролю господарської діяльності. Інформація, що отримується в системі управлінського обліку, відображає всі особливості роботи підприємства, вона повністю розкриває економічні, технічні, технологічні й фінансові можливості діяльності підприємства. [11, с. 123].

I.В. Гончарук відмічає, що якісне управління будь-яким суб'єктом господарювання незалежно від форми власності у сучасних умовах неможливе без раціональної побудови системи бухгалтерського обліку та оподаткування [12, с. 18].

Вагомість облікової інформації підвищується за умови, коли облікова інформація повною мірою задовольняє інформаційні запити управлінського персоналу та не є надлишковою, тобто містить в собі всі характеристики релевантної інформації [13, с. 25].

Прийняття короткострокових рішень грунтується на аналізі поточного економічного стану $\mathrm{i}$ на оцінці матеріальних, трудових і фінансових ресурсів, які підприємство має в розпорядженні. Для вироблення короткострокових рішень необхідно мати дані про ціни на продукцію конкуруючих підприємств, очікуваному попиті на продукцію за альтернативними цінами і прогнозованих при різних варіантах виробництва витратах. Ця інформація знадобиться на різних рівнях управління для прийняття рішень про встановлення цін і обсяг виробництва продукції.

Перш ніж прийняти правильне рішення, слід визначити цілі чи окреслити коло завдань, що дозволить тим особам, які приймають рішення оцінити переваги одного варіанту дій над іншими [13, с. 16].

Оскільки в точності реалізувати заплановані рішення, сформовані за результатами аналізу і у рамках заходів, зроблених на етапі контролю і регулювання, практично неможливо, то зазвичай кожне рішення обгрунтовується в межах відомих обмежень і прийнятних допущень. Тому, якщо відхилення фактичних результатів не перевищують визначених заздалегідь, то цикл прийняття рішень завершується комплексною оцінкою фактично досягнутого результату. Комплексна оцінка ефективності рішень, що приймаються, здійснюється шляхом аналізу загальної ефективності господарської діяльності підприємства, на основі чого уточнюються її цілі і завдання на наступний період.

Загалом, технологічний процес прийняття управлінських рішень можна представити у вигляді послідовності етапів і процедур, що мають між собою прямі і зворотні зв'язки, які утворюють інформаційні потоки. При цьому в процесі прийняття і реалізації управлінських рішень прийнято виділяти наступні етапи:

- визначення цілей;

- забезпечення комплексності рішення;

- забезпечення інформаційними джерелами для підготовки рішення;

- перевірка наслідків реалізації можливих варіантів;

- оцінка результатів. 
Розглянемо детальніше ці етапи, запропоновані О.М. Гайдаєнко та Н.С. Шевчук [10, с. 11].

Визначення цілей прийняття рішення повинне містити характеристику проблемної ситуації, а також при необхідності інші відомі елементи вирішуваної задачі. При цьому визначення цілей служить підставою для подальшого вироблення і прийняття відповідного управлінського рішення.

Проблемна ситуація у визначенні цілей прийняття рішення зазвичай описується змістовно, але якщо це можливо і за допомогою кількісних параметрів. При цьому мають бути сформульовані умови, пов'язані з даною проблемою, визначені причини ії виникнення і розвитку. Для цього необхідно, передусім, провести аналіз економічного середовища підприємства. Опис проблемної ситуації повинен закінчуватися коротким змістовним формулюванням проблеми, яку необхідно вирішувати, а також постановкою цілей, пов'язаних з ії реалізацією.

Вирішення економічних завдань завжди здійснюється в умовах різних обмежень: фінансових, матеріальних, правових, етичних і т. д. Тому важливо чітко сформулювати обмеження, які повинні враховуватися при прийнятті рішення в конкретній проблемній ситуації.

Завдання прийняття рішення формується таким чином: в умовах проблемної ситуації, відведеного часу i ресурсів необхідно доповнити цю ситуацію різними альтернативними ситуаціями, сформулювати безліч цілей, обмежень, альтернативних рішень, зробити оцінку переваг рішень і знайти найкраще з них, керуючись сформульованим критерієм вибору [10, с. 12]. Особливу роль при цьому відіграє правильний опис вирішення задачі, який неможливо здійснити без формування і глибокого аналізу проблемної ситуації.

Виявлення причин виникнення проблемної ситуації є найважливішою умовою прийняття правильного рішення. Знання причин дозволяє своєчасно виявити проблему у момент іiі зародження. Від оперативності організаційно-економічного управління залежить ефективність реалізації профілактичних заходів превентивного характеру, які запобігають появі або поглибленню проблемних ситуацій [10, с. 31].

Відсутність знань про причини виникнення проблемної ситуації призводить до того, що проблема може виникнути несподівано. В цьому випадку часу на прийняття правильного рішення може не вистачити.

Виявлення причин виникнення проблемної ситуації можливо на основі достовірної інформації про характер і особливості функціонування об'єкта управління. Проте збір фактичного матеріалу про проблемну ситуацію пов'язаний з додатковими витратами і часом.

Причинами проблемних ситуацій можуть стати чинники внутрішнього і зовнішнього середовища діяльності підприємства [10, с. 32].

Поява однієї проблеми спричиняє за собою виникнення інших. Тому необхідно мати на увазі, що будь-яке рішення може торкнутися усіх сфер виробничо-господарської діяльності підприємства.

Своєчасність управлінських рішень досягається за допомогою постійної та системної аналітичної обробки інформації, яка дає можливість оперативно виявляти негативні чи позитивні тенденції в діяльності підприємств, можливі їх наслідки та чинники, які на них впливають [14, с. 446-447]. Конкретне управлінське рішення приймається на основі аналізу спеціально відібраної для цієї мети інформації. Дані поступають 3 різних джерел, формуються в різних підсистемах підприємства та у зовнішньому бізнес-середовищі (рис. 2) [6, с. 51].

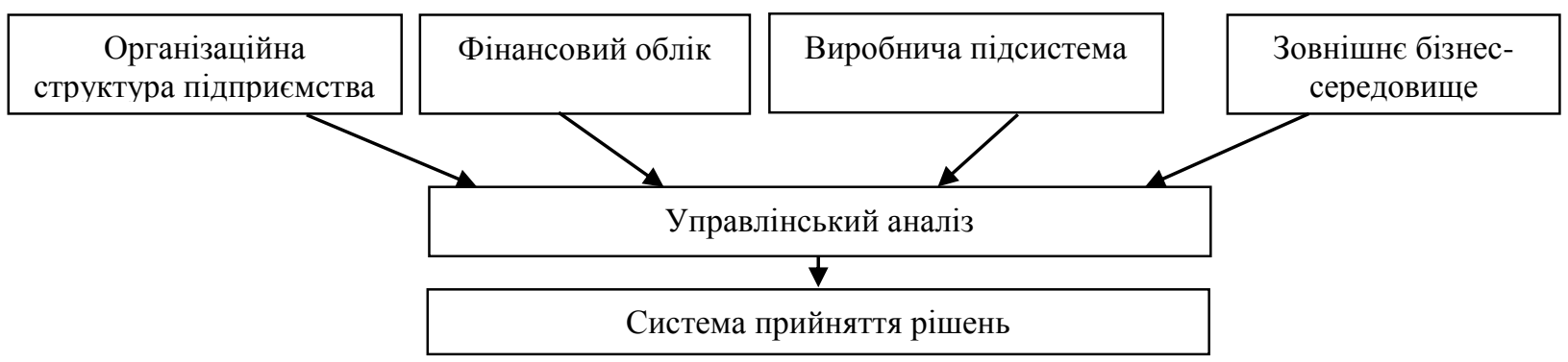

Рuc. 2. Інформація в системі прийняття управлінських рішень

Джерело: побудовано авторами на основі [6, с.51]

Поточний аналіз інформації дозволяє мати певну уяву про наявність або про відсутність відхилень від заданих значень досліджуваного процесу, а також виявити ту або іншу назріваючу проблему. Причому Г.М. Калетнік та В.М. Ціхановська наголошують на визначених вимогах до інформації: значимість, повнота, достовірність, доступність та своєчасність [9, с. 44]. 
При аналізі отриманої інформації залежно від поставленої мети застосовуються різні методи. Якісна інформація вивчається за допомогою: порівняння, аналогій, аналізу, синтезу, абстракції, узагальнення, індукції, дедукції. Для обробки і аналізу інформації широко використовуються кількісні методи: групування, табличний метод, обчислення відсотків, кореляційно-регресійний аналіз і інші економіко-математичні методи [1, с. 47-70].

Наявність заздалегідь обробленої інформації у вигляді зведень, доповідей, прогнозів і висновків дає можливість менеджерам, які приймають рішення зробити висновки про розвиток проблемної ситуації і про ступінь її вирішення.

Головним інструментом реалізації ступеня вирішуваної проблеми може бути або інтуїція особи, що приймає рішення або добре сформульоване і формалізоване завдання.

Висновки і оцінки, зроблені на етапі аналізу проблемної ситуації мають бути цілком достатні для того, щоб знайти декілька варіантів рішення поставленої задачі.

Передусім, оптимальність або раціональність управлінського рішення залежить від числа відомих альтернатив. Чим більше відомо варіантів вирішення якого-небудь питання, тим більше вірогідності прийняття оптимального рішення. Зазвичай вибір кращого 3 великої кількості варіантів призводить до вигіднішого результату, ніж вибір кращого варіанту серед невеликого їх числа. При цьому особливий інтерес представляє використання евристичних методів.

Є.В. Мних зазначав, що альтернативна основа аналітичного пошуку передбачає не лише багатокритеріальну оптимізацію та формування зони прийняття управлінських рішень, а й рейтингову оцінку будь-якого варіанту змін. В даному випадку мету розташовують в порядку переваг, керуючись певними критеріями важливості, що визначають порядок їх досягнення. Аналітичне забезпечення набирає консалтингової основи, де визначальною є економічна вигода. Найбільшою мірою цьому сприяє нова система обліку, яка адаптована до міжнародних стандартів фінансової звітності. Рейтингова оцінка дає змогу обрати оптимальний план управлінських дій при обмежених ресурсних можливостях. Проблема рейтингової оцінки тісно пов'язана 3 питанням визначення інтегральних показників [6, с. 34].

Управлінська практика свідчить про те, що при прийнятті і реалізації рішень певна частина керівників використовує неформальні методи, які грунтуються на аналітичних здібностях осіб, що приймають управлінські рішення. У більшій частині неформальні методи базуються на інтуїції менеджера. Їх перевага полягає в тому, що приймаються вони оперативно, недолік - неформальні методи не гарантують від вибору помилкових (неефективних) рішень, оскільки інтуїція іноді може підвести менеджера. О.М. Гайдаєнко та Н.С. Шевчук Н.С. відносять до них економікоматематичне моделювання, побудову імітаційних моделей і систем, що дозволяє прогнозувати фінансові результати в умовах невизначеності та ризику. При цьому розвиток інформаційних технологій дозволяє використовувати для управлінського аналізу імітаційне моделювання для вирішення слабо структурованих завдань, яке значною мірою спирається на теорію інформаційних систем, математику, теорію ймовірності, статистику. В процесі побудови імітаційної моделі разом 3 цим можуть використовуватися регресійний і кореляційний види аналізу [10, с. 10].

Етап оцінки результатів $є$ найбільш трудомістким через значні витрати інтелектуального ресурсу. На цьому етапі основна робота виконується особами, які приймають рішення на основі критерію вибору, який формується на основі усвідомлення усієї зібраної і обробленої раніше інформації.

Є.В. Мних звертав свою увагу на те, що результатом аналітичних досліджень є формування банку рекомендацій наукового, інженерно-технічного та організаційно-економічного характеру щодо зміни та вдосконалення різних напрямів роботи підприємства. Систематизація виявлених проблем і “вузьких місць” дасть змогу з'ясувати, наскільки їх розв'язання, згідно з пропозиціями аналітиків, здатне зміцнити економічну систему. Автор пропонує всі пропозиції згрупувати. У першу групу включити усі пропозиції, які стосуються вдосконалення окремих елементів досліджуваної системи на основі часткових розв'язків без залучення великих інвестицій. У другу групу об'єднати пропозиції, пов'язані з поетапними цілеспрямованими структурними змінами роботи за рахунок проведення організаційно-технічних заходів при нагромадженні достатньо надійних, високоефективних рішень і власних (частково залучених) коштів для іiї реалізації. Третю групу становлять пропозиції, спрямовані на докорінну зміну системи чи ії структурних елементів на основі принципово нових рішень при вкладеннях значних коштів на конверсію виробництва [6, с. 93].

І.О. Щебликіна та Д.В. Грибова Д.В. вважають, що “... у досягненні ефективності рішень особливу роль відіграють методи доведення прийнятих рішень до виконавців. Доведення рішень до виконавців розпочинається зазвичай з розбиття альтернативи на групові і індивідуальні завдання 
і підбору виконавців. В результаті кожен співробітник отримує конкретне завдання, яке знаходиться в прямій залежності від його службових обов'язків і цілого ряду інших об'єктивних і суб'єктивних чинників. Вважається, що уміння передати завдання виконавцям є головним джерелом ефективності прийнятого рішення. У зв'язку з цим виділяють чотири головні причини невиконання рішень:

- якщо рішення було недостатньо чітко сформульовано менеджером;

- якщо рішення було ясне і чітко сформульоване, однак виконавець його погано усвідомив;

- рішення було чітко сформульоване і виконавець його добре усвідомив, але у нього не було необхідних умов і засобів для його виконання;

- рішення було грамотно сформульоване, виконавець його засвоїв і мав усі необхідні засоби для його виконання, але у нього не було внутрішньої згоди з варіантом рішення, запропонованим менеджером. Виконавець в даному випадку може мати свій, ефективніший, на його думку, варіант рішення цієї проблеми.

Вищевикладене свідчить про те, що ефективність рішення залежить не лише від його оптимальності, але і від форми доведення до виконавців (оформлення рішень і особистих якостей керівників і виконавців) ..." [15]. Залежно від мети управлінського аналізу, формують його етапи (рис. 3) [7, с. 24].

\begin{tabular}{|c|}
\hline Послідовність етапів управлінського аналізу \\
\hline \hline Попередній огляд узагальнюючих показників \\
\hline \multicolumn{1}{|}{$\downarrow$} \\
\hline Поглиблений аналіз показників \\
\hline $\begin{array}{c}\downarrow \\
\text { Комплексна оцінка ефективності фінансово-господарської діяльності для } \\
\text { формування управлінських рішень }\end{array}$ \\
\hline
\end{tabular}

\section{Рис. 3. Послідовність етапів управлінського аналізу}

Джерело: побудовано авторами на основі [7, с.24]

Отже, управлінський аналіз з одного боку є видом економічного аналізу, а 3 іншого складовою частиною управлінського обліку, призначеною для задоволення інформаційних потреб менеджменту з метою прийняття оптимальних управлінських рішень.

Враховуючи особливості управлінського аналізу, зазначені нами вище, пропонуємо дати повне і найбільш точне визначення управлінського аналізу. Управлінський аналіз - це аналіз, який носить конфіденційний характер, орієнтований на внутрішніх користувачів, має перспективну орієнтацію та проводиться з урахуванням галузевої специфіки аналізованого об'єкту.

Висновки. Термін “управлінський аналіз” вказує на спорідненість управлінського аналізу 3 управлінським обліком і економічним аналізом. 3 одного боку він базується на даних управлінського обліку, а з іншого боку в процесі проведення використовує методи і процедури економічного аналізу.

Таким чином, управлінський аналіз є стержневим чинником підвищення ефективності прийняття рішень в процесі управління складними економічними об'єктами. Це зумовлено тим, що без аналізу економічного середовища підприємства неможливо сформувати проблемну ситуацію, визначити мету функціонування і вибрати найбільш ефективні шляхи їх реалізації.

Подальшими дослідженнями $є$ детальне вивчення етапів стратегічного управлінського аналізу 3 врахуванням STEP-факторів i конкурентоспроможності сільськогосподарського підприємства.

\section{Список використаних джерел}

1. Андрєєва Г.І., Андрєєва В.А. Організація і методика економічного аналізу: навч. посіб. Суми, 2009. $353 \mathrm{c}$.

2. Серединська В.М., Загородна О.М., Федорович Р.В. Економічний аналіз: навч. посіб. Тернопіль, 2010. 624 с.

3. Лучко М.Р., Жукевич С.М., Фаріон А.І. Фінансовий аналіз: навч. посіб. Тернопіль, 2016.304 с.

4. Фінансовий аналіз: навч. посіб. / Школьник I.О., Боярко I.М., Дейнека О.В. та ін. Київ : Центр учбової літератури, 2016. 368 с. 


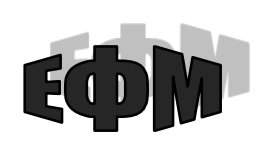

http://efm.vsau.org/

5. Калетнік Г.М., Ціхановська В.М. Фінансовий менеджмент: навч. посіб. Київ, 2010. 320 с.

6. Мних Є.В. Економічний аналіз: підручник. Вид. 2-ге, перероб. та доп. Київ: Центр навчальної літератури, 2005. 412 с.

7. Никифорова Н. А., Тафинцева В.Н. Управленческий анализ: учебник для бакалавриата и магистратуры. 3-е изд., испр. и доп. Москва, 2018. 413 с.

8. Вахрушина М.А. Управленческий анализ: учеб. пособие. 6-е изд., испр. - Москва: ОмегаЛ, 2010. 399 c.

9. Мулик Т.О., Гордієнко М.І. Методичні підходи до управлінського аналізу в умовах інтеграційних процесів. ЕКОНОМІКА. ФІНАНСИ. МЕНЕДЖМЕНТ: актуальні питання науки $i$ практики. 2017. № 7. С. 7-19.

10. Гайдаєнко О. М., Шевчук Н.С. Управлінський аналіз: навч. посіб. Одеса, 2015. 151 с.

11. Марущак Л. Концептульні засади побудови управлінського обліку. Галицький економічний вісник. 2014. Том 45. № 2. С. 122-127.

12. Гончарук I.В., Плахтій Т.Ф., Старосуд В.І. Система обліку та оподаткування на дослідноселекційній станції ІБК і ЦБ НААН України: стан та напрями удосконалення. ЕКОНОМІКА. ФІНАНСИ. МЕНЕДЖМЕНТ: актуальні питання науки і практики. 2017. № 11. С.17-30.

13. Бухгалтерський облік в управлінні підприємством: навч. посіб. / О.Л. Лаговська, С.Ф. Легенчук, В.І. Кузь, С.В. Кучер. Житомир: Житомирський державний технологічний університет, 2017. $416 \mathrm{c}$.

14. Томчук О.Ф., Томчук В.В. Управлінські рішення та їх аналітичне забезпечення. Розвиток бухгалтерського обліку: теорія, професія, між предметні зв'язки: зб. матеріалів IX Міжнар. наук.практ. конф. Київ: ННЦ “ІАЕ”, 2015. С.445-448.

15. Щебликіна I.О., Грибова Д.В. Основи менеджменту: навч. посіб. Мелітополь, 2015. 480 c. URL: https://pidruchniki.com/75177/menedzhment/umovi_efektivnosti_upravlinskih_rishen (дата звернення: 10.03.2019).

\section{Reference}

1. Andrieieva, H.I., \& Andrieieva, V.A. (2009) Orhanizatsiia i metodyka ekonomichnoho analizu [Organization and methods of economic analysis]. Sumy: DVNZ «UABS NBU» [in Ukrainian].

2. Seredynska, V.M., Zahorodna, O.M., \& Fedorovych R.V. (2010) Ekonomichnyi analiz [Economic analysis]. Ternopil: Aston [in Ukrainian].

3. Luchko, M.R., Zhukevych, S.M., \& Farion, A.I. (2016) Finansovyi analiz [Financial analysis]. Ternopil: TNEU [in Ukrainian].

4. Shkolnyk, I.O., Boiarko, I.M., \& Deineka O.V. ta in. (2016) Finansovyi analiz [Financial analysis]. Kyiv: Tsentr uchbovoi literatury [in Ukrainian].

5. Kaletnik, H.M., \& Tsikhanovska, V.M. (2010) Finansovyi menedzhment [Financial management]. Kyiv: "Khai-Tek Pres" [in Ukrainian].

6. Mnykh, Ye.V. (2005) Ekonomichnyi analiz [Economic analysis]. Kyiv: Tsentr navchalnoi literatury [in Ukrainian].

7. Nykyforova, N. A., \& Tafyntseva, V.N. (2018) Upravlencheskyi analyz [Administrative analysis]. Moskva: Yurait [in Russian].

8. Vakhrushyna, M.A. (2010) Upravlencheskyi analyz [Administrative analysis]. Moskva: OmehaL [in Russian].

9. Mulyk, T.O., \& Hordiienko, M.I. (2017) Metodychni pidkhody do upravlinskoho analizu v umovakh intehratsiinykh protsesiv. [Methodical approaches to the management of the analysis in terms of integration processes]. EKONOMIKA. FINANSY. MENEDZhMENT: aktualni pytannia nauky i praktyky, 7, 7-19 [in Ukrainian].

10. Haidaienko, O. M., \& Shevchuk N.S. (2015) Upravlinskyi analiz [Management analysis]. Odesa: ONEU [in Ukrainian].

11. Marushchak, L. (2014) Kontseptulni zasady pobudovy upravlinskoho obliku. [Konceptulnì principles of construction of managerial accounting]. Halytskyi ekonomichnyi visnyk, Tom 45, 2, $122-127$ [in Ukrainian].

12. Honcharuk, I.V., Plakhtii, T.F., \& Starosud, V.I. (2017) Systema obliku ta opodatkuvannia na doslidno-selektsiinii stantsii IBK i TsB NAAN Ukrainy: stan ta napriamy udoskonalennia. [The system of accounting and taxation at the experimental station selection CLAIM and the CENTRAL BANK of Ukraine: the State and directions of perfection ] EKONOMIKA. FINANSY. MENEDZhMENT: aktualni pytannia nauky i praktyky, 11, 17-30. [in Ukrainian].

13. Lahovska, O.L., Lehenchuk, S.F., Kuz V.I., \& Kucher S.V. (2017). Bukhhalterskyi oblik v upravlinni pidpryiemstvom [Accounting in business management]. Zhytomyr: Zhytomyrskyi derzhavnyi tekhnolohichnyi universytet. [in Ukrainian]. 
14. Tomchuk, O.F., \& Tomchuk, V.V. (2015) Upravlinski rishennia ta yikh analitychne zabezpechennia [Management solutions and their analytical support]. Rozvytok bukhhalterskoho obliku: teoriia, profesiia, mizh predmetni zv'iazky: zb. materialiv IKh Mizhnar. nauk.-prakt. konf. (pp. 445-448). Kyiv: NNTs "IAE" [in Ukrainian].

15. Shcheblykina, I.O., \& Hrybova, D.V. (2015) Osnovy menedzhmentu [Fundamentals of management]. Melitopol: Vydavnychyi budynok Melitopolskoi miskoi drukarni [in Ukrainian].

\section{Інформація про авторів}

ТОМЧУК Олена Феліксівна - кандидат економічних наук, доцент, доцент кафедри аналізу та статистики (21008, м. Вінниця, вул. Сонячна, 3, e-mail: olenatomchuk@ukr.net).

МУЛИК Тетяна Олексіївна - кандидат економічних наук, доцент, завідувач кафедри аналізу та статистики, Вінницький національний аграрний університет $(21008$, м. Вінниця, вул. Сонячна, 3, e-mail: mulyk_t_o@ukr.net).

ФЕДОРИШИНА Лідія Іванівна - кандидат історичних наук, доцент, доцент кафедри аналізу та статистики (21037, м. Вінниця, вул. Сонячна, 3, e-mail: fedorishina@i.ua).

TOMCHUK Olena - Candidate of Economic Sciences, Associate Professor, Associate Professor of the analysis and statistics Department 21008, Vinnytsia, 3, Soniachna str., e-mail: olenatomchuk@ ukr.net).

MULYK Tetiana - Candidate of Economic Sciences, Associate Professor, Head of the Analysis and Statistics Department, Vinnytsia National Agrarian University (21008, Vinnytsia, Sonyachna Str. 3, e-mail: mulyk_t_o@ukr.net).

FEDORYSHYNA Lydia - Candidate of History Sciences, Associate Professor, Associate Professor of analysis and statistics Department (21037, Vinnytsia, Sonyachna Str. 3, e-mail: fedorishina@i.ua).

ТОМЧУК Елена Феликсовна - кандидат экономических наук, доцент, доцент кафедры анализа и статистики (21008, г. Винница, ул. Солнечная, 3, e-mail: olenatomchuk@ukr.net).

МУЛЫК Татьяна Алексеевна - кандидат экономических наук, доцент, заведующая кафедрой анализа и статистики, Винницкий национальный аграрный университет (21008, г. Винница, ул. Солнечная, 3, e-mail: mulyk_t_o@ukr.net).

ФЕДОРИШИНА Лидия Ивановна - кандидат исторических наук, доцент, доцент кафедры анализа и статистики (21037, г. Винница, ул. Солнечная, 3, e-mail: fedorishina@i.ua).

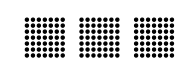

Регулирования независимого аудита в Украине в условиях евроинтеграции УАК 657.6

\section{РЕГУЛЮВАННЯ НЕЗАЛЕЖНОГО АУАИТУ В УКРАЇНІ В УМОВАХ ЄВРОІНТЕГРАЦІї $\odot$}

О.О. ГУЦАЛЕНКО, к.е.н., доцент, завідувач кафедри аудиту та державного контролю,

В.Ю. ФАБІЯНСЬКА к.е.н., доцент кафедри аудиту та держнавного контролю Вінницький національний аграрний університет (м. Вінниця)

У статті досліджено регулювання незалежного аудиту в Украӥні в умовах євроінтеграиійних процесів. Розглянуто критерії віднесення підприємств до мікро-, малих, середніх або великих а також особливі вимоги щодо складання ними фінансової звітності та ї̈ оприлюднення відповідно до Закону Украӥни "Про внесення змін до Закону Украйни "Про бухгалтерський облік та фінансову звітність в Украӥні" (щодо удосконалення деяких положень)”. Досліджено вимоги до підприємств, що становлять суспільний інтерес та, відповідно, підлягають обов'язковому аудиту. 